\title{
Baicalein induces apoptosis and autophagy of breast cancer cells via inhibiting PI3K/AKT pathway in vivo and vitro
}

This article was published in the following Dove Press journal:

Drug Design, Development and Therapy

\section{Wanjun Yan \\ Xingcong $\mathrm{Ma}$ \\ Xiaoyao Zhao \\ Shuqun Zhang}

Department of Oncology, The Second Affiliated Hospital, Xi'an Jiaotong University, Xi'an, China
Correspondence: Shuqun Zhang Department of Oncology, The Second Affiliated Hospital of Medical College, Xi'an Jiaotong University, Number 157, West 5th Road, Xi'an 710004, Shaanxi, China

Tel +86 I38 9/84 I249

Email zhangshuqunI97। I@aliyun.com
Purpose: Baicalein, a widely used Chinese herbal medicine, has shown anticancer effects on many types of human cancer cell lines. However, little is known about the underlying mechanism in human breast cancer cells. In this study, we examined the apoptotic and autophagic pathways activated following baicalein treatment in human breast cancer cells in vitro and in vivo.

Materials and methods: In in vitro study, we used MTT and clone formation assay to confirm the inhibitory role of baicalein on proliferation of MCF-7 and MDA-MB-231 breast cancer cells. Apoptosis was detected employing Hoechst 33258 staining, JC-1 staining, and flow cytometry. Autophagy was monitored by acridine orange staining and transmission electron microscopy observation. Quantitative real-time PCR and Western blot analysis were employed to study the effects of baicalein on PI3K/AKT signaling components of MCF-7 and MDA-MB-231 breast cancer cells. In in vivo study, the effect of baicalein was tested with a breast cancer cells transplantation tumor model.

Results: Our study showed that baicalein has the potential to suppress cell proliferation, induce apoptosis and autophagy of breast cancer cells in vitro and in vivo. Furthermore, baicalein significantly downregulated the expression of p-AKT, p-mTOR, NF- $\kappa \mathrm{B}$, and p-IкB while enhancing the expression of IKB in MCF-7 and MDA-MB-231 cells. It also decreased the $\mathrm{p}-\mathrm{AKT} / \mathrm{AKT}$ and $\mathrm{p}-\mathrm{mTOR} / \mathrm{mTOR}$ ratios.

Conclusion: Our study demonstrated that baicalein induces apoptosis and autophagy of breast cancer cells via inhibiting the PI3K/AKT signaling pathway in vivo and vitro. Our study revealed that baicalein may be a potential therapeutic agent for breast cancer.

Keywords: baicalein, breast cancer, apoptosis, autophagy, PI3K, AKT

\section{Introduction}

Breast cancer, one of the most commonly occurring female malignant tumors, with the increased incidence and much younger onset age recently, is a serious threat to women's health. ${ }^{1,2}$ Based on GLOBOCAN estimates, approximately 1.7 million new cancer cases and 521,900 deaths occurred in 2012 worldwide. ${ }^{3}$ Although there have been noteworthy advances in screening, surgery, and chemoradiotherapy techniques, the prognosis of patients remains little known. ${ }^{4,5}$ Hence, it is urgent to provide a new therapeutic strategy in cancer therapy.

Baicalein, a bioactive component extracted from the root of Scutellaria baicalensis Georgi, has been shown to have anti-tumor, anti-inflammatory, anticardiovascular disease, and antimicrobial activities, ${ }^{6}$ and so on. ${ }^{7,8}$ Numerous studies have revealed the anti-tumor properties of baicalein in many types of human 
cancer cell lines both in vitro ${ }^{9,10}$ and in vivo. ${ }^{11,12}$ The molecular mechanisms involved in the anti-tumor effects of baicalein are conjectured to be due to the modulation of multiple pathways including the PI3K/AKT signaling pathway and inhibiting cell proliferation and inducing cell apoptosis, activating the caspase cascade and the intrinsic (mitochondrial) apoptotic pathway, ${ }^{13,14}$ DNA fragmentation in malignant cells. ${ }^{15,16} \mathrm{Cao}$ et al ${ }^{17}$ reported that apigenin has also demonstrated anticancer activities, involving apoptosis- and autophagy-induction in breast cancer cells. Significantly, the study illuminated that autophagy plays a vital cytoprotective role in apigenininduced apoptosis. ${ }^{17}$

The PI3K/AKT signaling pathway plays a pivotal role in mammalian cell proliferation, differentiation, apoptosis, autophagy, and survival, ${ }^{18}$ and is a key regulator of authophagy. ${ }^{19}$ Activation/inhibition of the PI3K/AKT signaling pathway has been clarified to regulate survival of human cancer cells in vitro, ${ }^{20}$ as well as carcinogenicity, invasion and metastasis of human cancer cells in vivo. ${ }^{21}$ Baicalein-induced apoptosis and autophagy have been illustrated to be mediated through inhibition of the PI3K/ AKT signaling pathway in human renal carcinoma cells, ${ }^{16}$ glioma, ${ }^{18}$ human epidermoid carcinoma cells, ${ }^{22}$ and bladder cancer cells. ${ }^{23}$ Nevertheless, few studies have clarified the latent molecular mechanism of anticancer activity of baicalein on human breast cancer cells. Hence, the purpose of the present study was to ascertain potential mechanisms through which baicalein induces apoptosis and autophagy in MCF-7 and MDA-MB-231 breast cancer cells. And for all we know, the current study will provide new direct evidence that baicalein induces apoptosis and autophagy in breast cancer cells by inhibiting the PI3K/AKT signaling pathway.

\section{Ethical approval}

Female BALB/c nude mice (3-6 weeks old, body weight 18-20 g) were obtained from the Experimental Animal Center of Xi' an Jiaotong University (Xi'an, China). Animal experiments in this study were conducted according to the institutional guidelines for the care and use of animals and approved by the ethics committee of Xi'an Jiaotong University. Ethical approval for use of human cell lines was not needed as per Xi'an Jiaotong University ethical committee guidelines. The breast cancer cell lines used in the present study are all commonly used and subcultured cell lines obtained from public cell banks. They were not derived from our patients or healthy donors.

\section{Materials and methods Cell lines and chemicals}

The MCF-7 and MDA-MB-231 breast cancer cell lines were obtained from Shanghai Cell Biological Institute of the Chinese Academy of Science (Shanghai, China). DMEM, Giemsa stain, and FBS were obtained from Gibco (Thermo Fisher Scientific, Waltham, MA, USA). DMSO, Hoechst 33258, acridine orange (AO) stain Kit, Mitochondrial membrane potential assay kit with JC-1, the Annexin V-FITC Apoptosis Detection kit, MTT, LY294002, and baicalein (molecular weight [MW] 270.24) were purchased from Sigma-Aldrich Co. (St Louis, MO, USA). All antibodies (GAPDH, AKT, p-AKT, mTOR, p-mTOR, NF- $\kappa$ B, I $\mathrm{B}, \mathrm{p}-\mathrm{I} \kappa \mathrm{B}, \mathrm{Bcl}-2$, Bax, BECN1, and LC3) were purchased from Abcam (Cambridge, UK). Baicalein was dissolved in DMSO.

\section{Cell culture}

MCF-7 and MDA-MB-231 breast cancer cells were cultured in DMEM supplemented with $10 \% \mathrm{FBS}, 50 \mathrm{IU} / \mathrm{mL}$ penicillin, and $50 \mu \mathrm{g} / \mathrm{mL}$ streptomycin and maintained in humidified $5 \% \mathrm{CO}_{2}$ air at $37^{\circ} \mathrm{C}$.

\section{Animals}

Female BALB/c nude mice (3-6 weeks old, body weight 18-20 g) were obtained from the Experimental Animal Center of Xi'an Jiaotong University. Animal experiments in this study were conducted according to the recommended guidelines for the care and use of laboratory animals issued by the Chinese Council on Animal Research, and approved by the ethics committee of Xi' an Jiaotong University.

\section{Morphological cell changes}

MCF-7 and MDA-MB-231 cells were seeded in 12-well plates at a density of $3 \times 10^{5}$ cells/well and grown for 24 hours. Cells were treated with various concentrations $(0,10,20$, and $40 \mu \mathrm{M}$ ) of baicalein and grown at $37^{\circ} \mathrm{C}$, in $5 \% \mathrm{CO}_{2}$ and $95 \%$ air for 24 hours. For examining morphological changes, cells treated with baicalein were observed and photographed under a phase-contrast microscope.

\section{MTT assay}

The cell viability was assessed by MTT assay. Briefly, MCF-7 and MDA-MB-231 ( $4 \times 10^{3}$ cells/well) cells were seeded into 96-well plates and incubated in $5 \% \mathrm{CO}_{2}$ air at $37^{\circ} \mathrm{C}$. After 12 hours of incubation, the cells were treated with different concentrations of baicalein $(0,10,20$, and $40 \mu \mathrm{M})$ for 24 , 48 , and 72 hours. Subsequently, MTT ( $20 \mu \mathrm{L}$ of $5 \mathrm{mg} / \mathrm{mL}$ ) was added to each well and incubated at $37^{\circ} \mathrm{C}$ for 4 hours. 
The formazan crystals that formed were dissolved in $100 \mathrm{~mL}$ of DMSO after removal of the supernatant, and the cells were then incubated for another 10 minutes. The OD was recorded at $490 \mathrm{~nm}$ on a microplate reader (Bio-Tek Instruments, Inc., Winooski, VT, USA). The inhibition ratio (IR) was calculated as follows: IR $=(1-$ mean OD value of experimental group/ mean OD value of control group) $\times 100 \%$. Approximately $50 \%$ inhibition concentration (IC50) of baicalein at different time points was calculated using the Logit method. All experiments were repeated at least three times.

\section{Colony formation assay}

MCF-7 and MDA-MB-231 cells (1,000 cells/well) were seeded into 6-well plates. After adhesion cells were treated with baicalein $(0,10,20$, and $40 \mu \mathrm{M})$ for 48 hours and then cultured in DMEM at $37^{\circ} \mathrm{C}$ for 14 days. During this period, the cells were washed with PBS every 3 days, fixed with paraformaldehyde (4\%, 15 minutes), and stained with crystal violet $(0.1 \%, 15$ minutes $)$ and the numbers of colonies with $>50$ cells were counted with an Olympus digital camera (Olympus Corporation, Tokyo, Japan). All experiments were repeated at least three times.

\section{Hoechst 33258 staining for apoptosis}

MCF-7 and MDA-MB-231 cells $\left(2 \times 10^{5}\right.$ cells/well) were seeded in 12-well plates for 12 hours and treated with various concentrations of baicalein $(0,10,20$, and $40 \mu \mathrm{M})$ for 48 hours, washed with PBS, and then fixed in paraformaldehyde (4\%) for 15 minutes at room temperature. Sequentially, cells were stained with $100 \mu \mathrm{L}$ Hoechst 33258 in PBS for 15 minutes at room temperature. The stained cells were visualized from randomly selected fields under a fluorescence microscope (Leica Microsystems, Wetzlar, Germany). The nuclear condensation and fragmentation of cells were identified as the apoptotic cells.

\section{Measurement of mitochondrial membrane potential $(\Delta \Psi \mathrm{m})$}

MCF-7 and MDA-MB-231 cells were seeded in 12-well plates at a density of $2 \times 10^{5}$ cells/well for 12 hours and treated with different concentrations of baicalein $(0,10,20$, and $40 \mu \mathrm{M}$ ) for 48 hours to detect the changes of $\Delta \Psi \mathrm{m}$. Then, cells were harvested and washed with $\mathrm{PBS}$ and resuspended in JC- 1 at $37^{\circ} \mathrm{C}$ for 30 minutes in the dark. The stained cells were analyzed by a fluorescence microscope.

\section{AO staining}

MCF-7 and MDA-MB-231 cells $\left(1 \times 10^{5}\right.$ cells/well $)$ were suspended and seeded in a 12-well plate and incubated overnight.
After adherence, cells were treated with baicalein $(0,10,20$, and $40 \mu \mathrm{M}$ ) for 48 hours. After 48 hours, cells were stained with $\mathrm{AO}(1 \mu \mathrm{g} / \mathrm{mL})$ for 15 minutes in the dark, washed with PBS, and visualized under a fluorescence microscope (Olympus Corporation). All experiments were repeated for at least three times.

\section{Transmission electron microscopy (TEM) observation}

TEM was carried out to observe the ultrastructure of MCF-7 and MDA-MB-231 cells after incubation with $40 \mu \mathrm{g} / \mathrm{mL}$ baicalein for 48 hours. The cells were collected and fixed in ice-cold glutaraldehyde in $0.1 \mathrm{~mol} / \mathrm{L}$ phosphate buffer (PH 7.4) overnight, and then fixed in 1\% osmium tetroxide and dehydrated. Cells were impregnated with Epon. The ultrathin sections were contrasted with uranyl acetate and lead citrate for electron microscopy. Electron micrographs were observed through a transmission electron microscope (H7650; Hitachi Ltd., Tokyo, Japan).

\section{Flow cytometry analysis}

Flow cytometry assay was performed to measure cell apoptosis rates. Briefly, after treatment with various concentrations $(0,10,20$, and $40 \mu \mathrm{M})$ of baicalein for 48 hours, MCF-7 and MDA-MB-231 cells were collected and washed twice in PBS at room temperature. For apoptosis assays, cells $\left(1 \times 10^{6}\right)$ were counted and resuspended in $100 \mu \mathrm{L}$ annexin-V binding buffer solution. Subsequently, $5 \mu \mathrm{L}$ annexin V-FITC and $5 \mu \mathrm{L}$ propidium iodide (PI) were added, and incubated at room temperature for 15 minutes in the dark. The percentage of apoptotic cells was analyzed by flow cytometry using CellQuest software (BC Epics XL, Miami, FL, USA).

\section{Quantitative real-time PCR ( $q$ RT-PCR)}

qRT-PCR was conducted to quantify the expression of mRNA. Briefly, MCF-7 and MDA-MB-231 cells were treated with various concentrations $(0,10,20$, and $40 \mu \mathrm{M})$ of baicalein for 48 hours. Total cell RNA was extracted by Trizol according to the manufacturer's instructions. RNA was then reverse transcribed into cDNA with RevertAid First-Strand cDNA Synthesis Kit (TaKaRa, Tokyo, Japan). Sequentially, qRT-PCR reaction system was prepared following the manufacturer's instructions given in the SYBR ${ }^{\circledR}$ Premix Ex TaqII RT-PCR Kit (TaKaRa) using 100 ng cDNA. The primers applied in this current study are listed in Table 1. Finally, each sample was analyzed in triplicate by using a StepOnePlus Real-Time PCR System (Thermo Fisher Scientific). Relative quantification of genes was analyzed in 
Table I Primers used for qRT-PCR analysis

\begin{tabular}{l|l|l}
\hline \multirow{2}{*}{ Gene } & Primer sequence & Reverse $\mathbf{( 5}^{\prime} \mathbf{- 3}^{\prime} \mathbf{)}$ \\
\cline { 2 - 3 } & Forward $\left(\mathbf{5}^{\prime} \mathbf{- 3} \mathbf{\prime}\right)$ & CAGAGACAGCCA GGAGAAATCA \\
\hline Bcl-2 & TCGCCCTGTGGATGACTGA & TAGCAAAGTAGAAAAGGGCAACC \\
Bax & GCGATGAACTGGACAACA ACAT & CCAGGAGGAAGAAGGCTTGG \\
LC3 & GAGTGGAAGATGTCCGGCTC & CGGAATTCTCATTTGTTATAAAATTGTGAGG \\
BECNI & CGGGATCCATGGAAGGGTCTAAGACGTCC & GGTATCGTGGAAGAACTCATGAC \\
GAPDH & ATGCCAGTGAGCTTCCCGTCAGC &
\end{tabular}

Abbreviation: qRT-PCR, quantitative real-time PCR.

accordance with the $2-\Delta \Delta \mathrm{Ct}$ method $(\Delta \Delta \mathrm{Ct}=\Delta \mathrm{Ct}$ [treated $]-$ $\Delta \mathrm{Ct}$ [control]). GAPDH was used as endogenous control.

\section{Western blotting}

The total proteins were collected from MCF-7 and MDAMB-231 cells cultured with various concentrations $(0,10,20$, and $40 \mu \mathrm{M}$ ) of baicalein for 24 hours, 48 hours, and 72 hours. Protein concentrations were analyzed by the Bio-Rad Protein Assay Kit (Bio-Rad Laboratories Inc., Hercules, CA, USA). Then, the proteins were separated by $10 \%$ SDS-PAGE and transferred onto PVDF membranes (EMD Millipore, Billerica, MA, USA). The membranes were blocked with $5 \%$ non-fat milk for 2 hours at room temperature followed by incubation overnight at $4{ }^{\circ} \mathrm{C}$ with a primary antibody (GAPDH, AKT, p-AKT, mTOR, p-mTOR, NF-кB, IкB, and $\mathrm{p}-\mathrm{I \kappa B}$ ) at a dilution of $1: 1,000$. Subsequently, the membranes were washed three times with TBST and incubated with the appropriate HRP-conjugated secondary antibody $(1: 5,000)$ for 2 hours at room temperature. Protein bands were visualized using the chemiluminescence gel imaging system (G: BOX; Syngene, Cambridge, UK) and quantitated using the Image-Pro Plus 6.0 software. GAPDH was used as an internal control.

\section{Tumor xenograft study}

Female BALB/c nude mice (3-6 weeks old) were purchased from Experimental Animal Center of Xi'an Jiaotong University. Xenografts were established by subcutaneous injection of in vitro-cultured MCF-7 $\left(1 \times 10^{7} / 200 \mu \mathrm{L}\right)$ and MDA-MB-231 cells $\left(2 \times 10^{6}\right.$ cells $\left./ 200 \mu \mathrm{L}\right)$ into the second left breast pad of nude mice. When the tumor size grew up to approximately $100 \mathrm{~mm}^{3}$, the mice were randomly divided into different groups (five mice in each group) and baicalein $(100 \mathrm{mg} / \mathrm{kg})$ or vehicle (1\% carboxymethyl cellulose sodium) was administered by intra-gastric gavage once daily for 21 days. Additionally, tumor volume growth and body weight were measured every 3 days using vernier calipers. The tumor volume was measured as: $\mathrm{v}=\mathrm{a} \times \mathrm{b}^{2} / 2$ ( $\mathrm{a}$ is the length; $b$ is the width). Experiments were terminated at the
21 st day and the animals were anesthetized and sacrificed. Tumors were removed for further analysis.

\section{Immunohistochemistry}

Histological analysis was performed on tissue samples isolated from mouse xenografts. Briefly, $5 \mu \mathrm{m}$ sections were cut from all paraffin blocks and stained for p-AKT, Bax, and LC3. Immunohistochemical staining was conducted using Histostain ${ }^{\circledR}$-SP Kits according to the manufacturer's instructions. Sections were incubated with p-AKT (1:100), BAX (1:100), and LC3 (1:100) primary antibody at $4^{\circ} \mathrm{C}$ overnight. Images of sections were visualized using a Zeiss microscope (Carl Zeiss Meditec AG, Jena, Germany) and analyzed by Image-Pro Plus 6.0.

\section{Statistical analysis}

Experimental results are presented as mean \pm SD from at least three separate experiments. Comparisons involving various baicalein concentrations or different incubation times were conducted using one-way ANOVA or Student's $t$-test. Statistical significance was set at $P<0.05$. Statistical analyses were performed using SPSS software (version 11.0).

\section{Results}

\section{Baicalein inhibited the proliferation of breast cancer cells}

Morphological cell changes were examined using phasecontrast microscopy. Microscopic observations revealed that MCF-7 and MDA-MB-231 cells exposed to increasing concentrations $(0,10,20$, and $40 \mu \mathrm{M})$ of baicalein underwent significant morphological changes, including cell shrinkage and blebbing (Figure 1A).

To measure the effect of baicalein on the proliferation of MCF-7 and MDA-MB-231 cells that were exposed to 0, 10 , 20 , and $40 \mu \mathrm{M}$ of baicalein for 24,48 , and 72 hours, MTT assay was implemented. The results showed that baicalein significantly inhibited the proliferation of MCF-7 and MDA-MB-231 cells in a dose- and time-dependent manner 


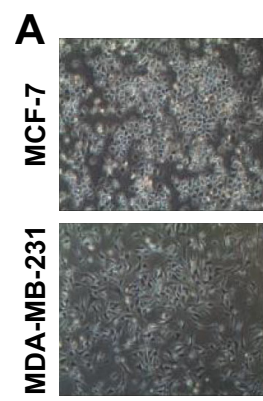

Control

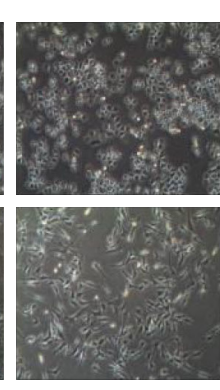

$10 \mu \mathrm{M}$

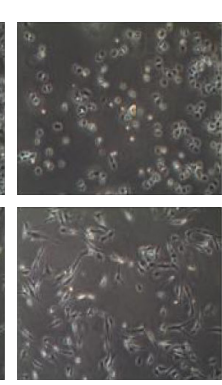

$20 \mu \mathrm{M}$

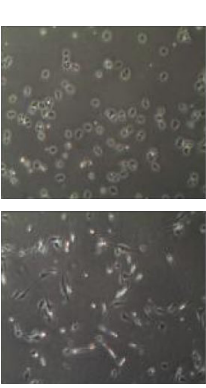

$40 \mu \mathrm{M}$
B MCF-7

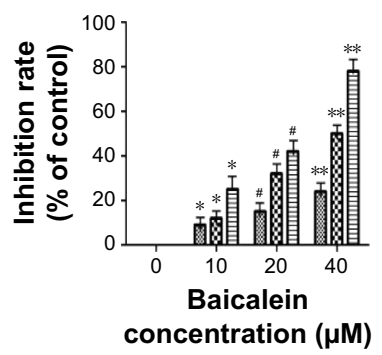

MDA-MB-231

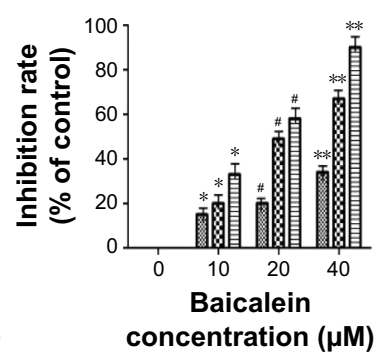

四 $24 \mathrm{~h} \quad 48 \mathrm{~h}$ 目 $72 \mathrm{~h}$

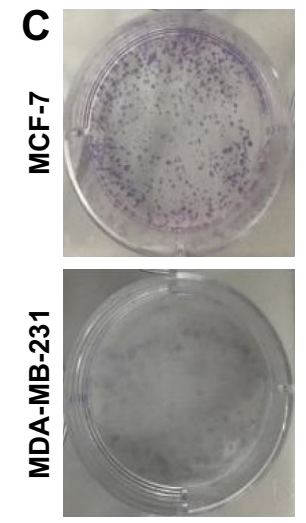

Control

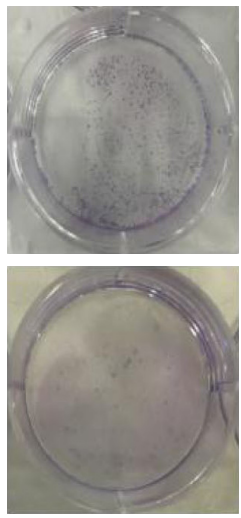

$10 \mu \mathrm{M}$

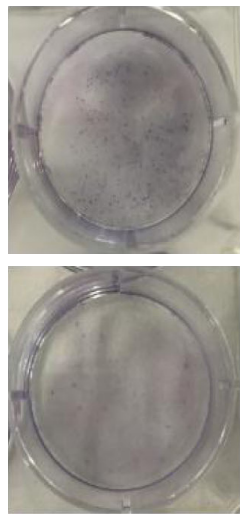

$20 \mu \mathrm{M}$

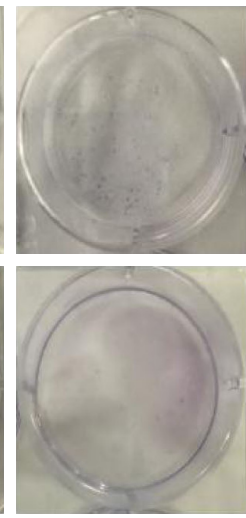

$40 \mu \mathrm{M}$

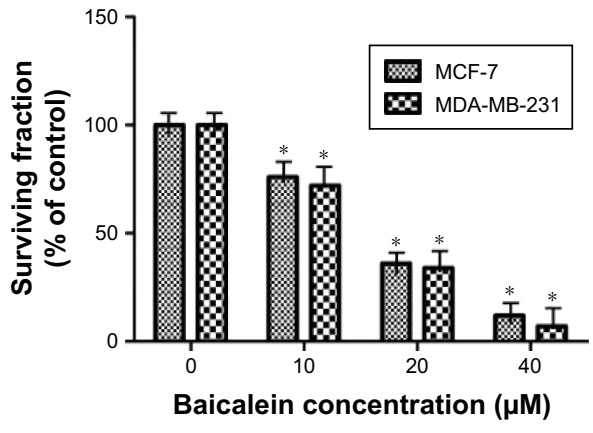

Figure I Morphological changes and cell viability of MCF-7 and MDA-MB-23I cells following treatment with baicalein.

Notes: (A) Cells after treatment with 0, 10, 20, and $40 \mu \mathrm{M}$ baicalein for 24 hours ( $\times 100)$. (B) Dose- and time-dependent effects of baicalein on MCF-7 and MDA-MB-23। cell viability after cells were cultured with various concentrations of baicalein for 24,48 , and 72 hours are demonstrated. Findings are presented as the mean \pm SD for three independent experiments, ${ }^{\sharp} P<0.05$. (C) Colony formation and the number of colonies of MCF-7 and MDA-MB-23I cells following treatment with baicalein at varying concentrations. Findings are presented as mean $\pm S D$ for three independent experiments. $* P<0.05, * * P<0.01$.

$(P<0.05, P<0.01$, Figure 1B). The IC50 values $(\mu \mathrm{M})$ of baicalein in breast cancer cells are presented in Table 2. The IC50 values of baicalein at 24,48 , and 72 hours were 51.06 , 22.16, and $13.98 \mu \mathrm{M}$ and $60.12,27.98$, and $19.01 \mu \mathrm{M}$ in MCF-7 and MDA-MB-231 cells, respectively.

Baicalein also suppressed the colony formation of MCF-7 and MDA-MB-231 cells as shown by the plate colony formation assay. As shown in Figure 1C, the numbers of colonies that formed for preparations treated with baicalein at 10,20 , and $40 \mu \mathrm{M}$ were $118 \pm 2.6,63 \pm 6.2$, $25 \pm 3.7$ and $85 \pm 1.6,51 \pm 6.7,19 \pm 3.6$ in MCF-7 and MDAMB-231 cells respectively $(P<0.05)$. These results suggest that baicalein has anti-proliferative effects on breast cancer cells.

Table 2 The IC50 values $(\mu \mathrm{M})$ of baicalein in breast cancer cells

\begin{tabular}{l|l|l|l}
\hline Cell lines & $\mathbf{2 4}$ hours & $\mathbf{4 8}$ hours & $\mathbf{7 2}$ hours \\
\hline MCF-7 & 51.06 & 20.12 & 13.98 \\
MDA-MB-23I & 60.12 & 27.96 & 19.01 \\
\hline
\end{tabular}

Abbreviation: IC50, 50\% inhibition concentration.

\section{Baicalein induced cell apoptosis in breast cancer cells}

To evaluate the effect of baicalein on breast cancer cell apoptosis, Hoechst staining 33258, which is sensitive to DNA and is used to assess changes in cellular nuclear morphology, was conducted in our study. In our study, MCF-7 and MDAMB-231 cells were cultured with different concentrations $(0,10$, 20 , and $40 \mu \mathrm{M}$ ) of baicalein for 48 hours. Results indicated that baicalein showed a potent effect on nuclear condensation when compared with the control cells demonstrated that baicalein was effective in inducing cellular apoptosis (Figure 2A).

To further assess whether baicalein affects apoptosis, mitochondrial membrane potential $(\Delta \Psi \mathrm{m})$ changes, which are key events that take place during drug-induced apoptosis, ${ }^{25,26}$ were examined using the fluorescent probe JC-1. MCF-7 and MDA-MB-231 cells were pre-treated with various concentrations $(0,10,20$, and $40 \mu \mathrm{M})$ of baicalein for 48 hours to detect the changes of $\Delta \Psi \mathrm{m}$. In normal cells, JC-1 accumulates and forms aggregations characterized by red fluorescence in the mitochondria and also in the cytoplasm as a monomer 
A
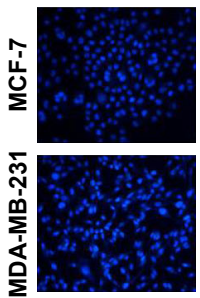

Control

B

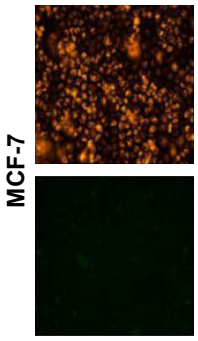

Control

C

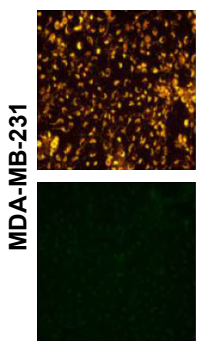

Control

D
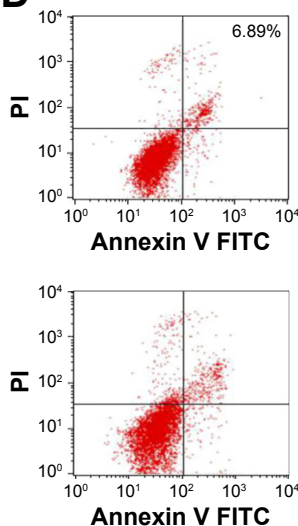

Control
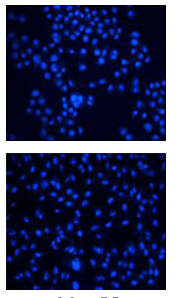

$10 \mu \mathrm{M}$

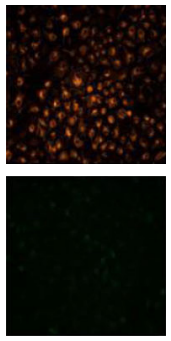

$10 \mu \mathrm{M}$
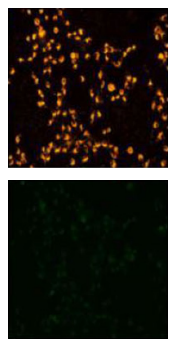

$10 \mu \mathrm{M}$
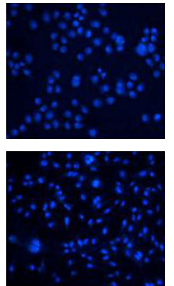

$20 \mu \mathrm{M}$

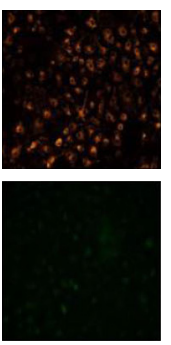

$20 \mu \mathrm{M}$
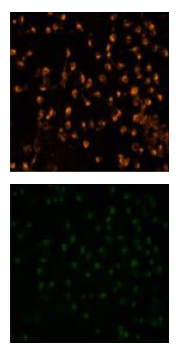

$20 \mu \mathrm{M}$
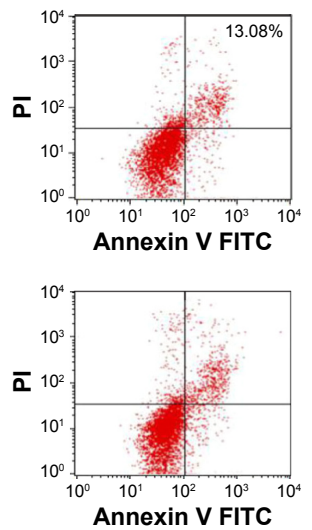

$10 \mu \mathrm{M}$
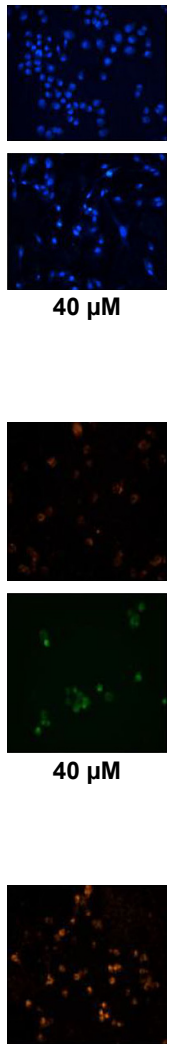

$40 \mu \mathrm{M}$

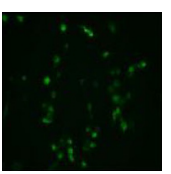

$40 \mu \mathrm{M}$
E

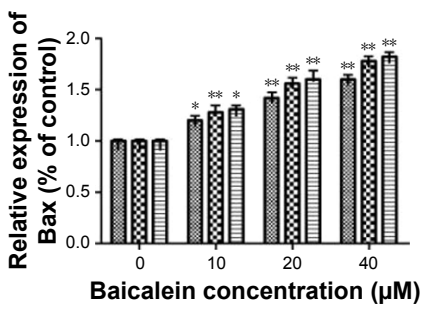

MDA-MB-231

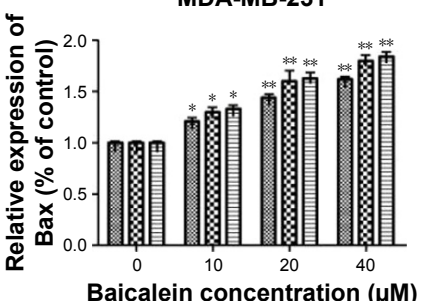

MCF-7

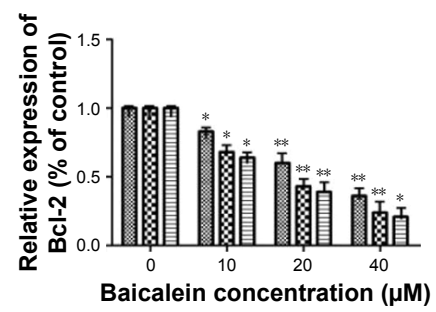

MDA-MB-231

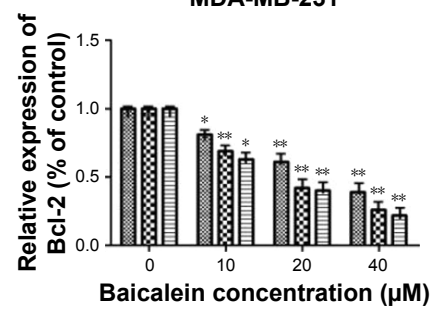

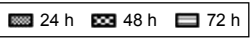

F

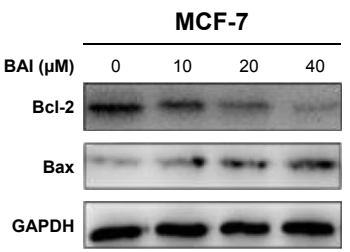

MDA-MB-231

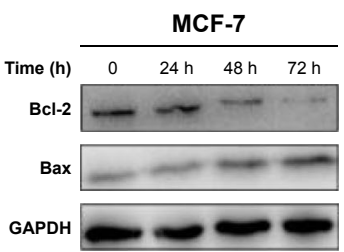

\begin{tabular}{cccc}
\multicolumn{4}{c}{ MDA-MB-231 } \\
\hline 0 & $24 \mathrm{~h}$ & $48 \mathrm{~h}$ & $72 \mathrm{~h}$ \\
\hline
\end{tabular}
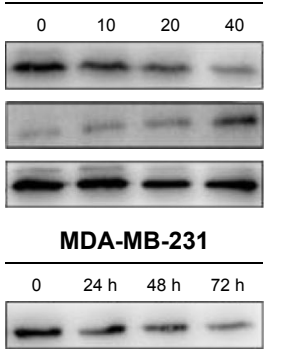

$-1-1-$

GAPDH
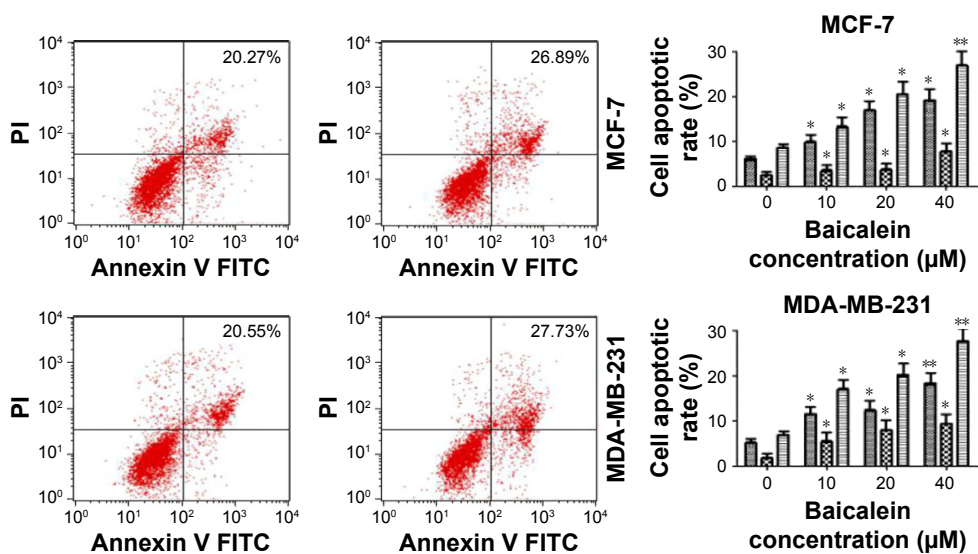

$20 \mu \mathrm{M}$
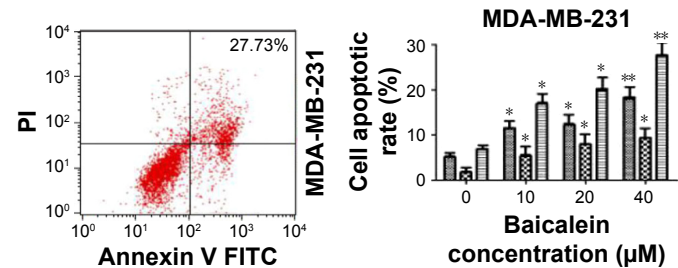

$40 \mu \mathrm{M}$

$\square$ Early apoptotic rate Late apoptotic rate

Figure 2 Detection of apoptotic morphological changes in MCF-7 and MDA-MB-23I cells treated with baicalein at 0, I0, 20, and $40 \mu \mathrm{M}$ concentrations for 48 hours. Notes: (A) Nuclei were stained with Hoechst 33258 and examined by fluorescence microscopy (MCF-7 and MDA-MB-23I cells [200× magnification]). (B, C) Baicalein triggered mitochondrial injury. Drops in mitochondrial membrane potential $(\Delta \Psi \mathrm{m})$ were assessed by JC-I staining of MCF-7 and MDA-MB-23I cells treated with test baicalein and were then examined by fluorescence microscopy (B: MCF-7 cell, C: MDA-MB-23I cell [200× magnification]). (D) Baicalein induced dose-dependent apoptosis in MCF-7 and MDA-MB-23I cells. The MCF-7 and MDA-MB-23I cells were treated with baicalein (0, 10, 20, and $40 \mu \mathrm{M})$ for 48 hours and stained with FITC-annexin V and PI. The percentage of surviving cells is shown in the lower left quadrant; and the percentages of early-stage and late-stage apoptotic cells are shown in the lower right and upper right quadrants, respectively. The apoptosis induced by baicalein was quantified. The data are presented as the mean \pm SD of three independent experiments. (E, F) Baicalein induced the activation of apoptotic-related genes and proteins in MCF-7 and MDA-MB-23I cells. After treatment with baicalein (0, I0, 20, and 40 $\mu$ mol/L) for 24, 48, and 72 hours, cell lysates were prepared and qRT-PCR and Western blot analysis were performed against Bax and Bcl-2. GAPDH was used as a loading control. The results shown are representative of at least three independent experiments. $* P<0.05, * * P<0.01$.

Abbreviations: PI, propidium iodide; qRT-PCR, quantitative real-time PCR. 
characterized by green spectral fluorescence. During apoptosis, the $\Delta \Psi \mathrm{m}$ changes, consequently, JC-1 aggregates transform into monomers leading to loss of red fluorescence. Hence, changes of the $\Delta \Psi \mathrm{m}$ are manifested via reduced ratio of red to green fluorescence. ${ }^{26}$ The red and green fluorescence were measured by a fluorescence microscope. With increasing dose of baicalein, the $\triangle \Psi \mathrm{m}$ was decreased in MCF-7 and MDA-MB-231 cells. The results indicated that baicalein on the levels of $\Delta \Psi \mathrm{m}$ were dose-dependent in breast cancer cells (Figure 2B and C).

Subsequently, we tested whether baicalein modulates cell apoptosis in MCF-7 and MDA-MB-231 cells by annexin V-FITC/PI staining and flow cytometry. The results revealed that baicalein increased the apoptosis rate of MCF-7 and MDA-MB-231 cells, with an apoptotic rate estimated at $26.89 \% \pm 0.96 \%$ and $27.73 \% \pm 0.23 \%$ in $40 \mu \mathrm{M}$ baicalein group, $20.55 \% \pm 0.62 \%$ and $20.27 \% \pm 0.36 \%$ in $20 \mu \mathrm{M}$ baicalein group, $13.08 \% \pm 0.78 \%$ and $16.94 \% \pm 0.86 \%$ in $10 \mu \mathrm{M}$ baicalein group, and $8.62 \% \pm 0.34 \%$ and $6.89 \% \pm 0.65 \%$ in the control group respectively, and clearly indicated that baicalein induced breast cancer cells' apoptosis in a dose-dependent manner $(P<0.05, P<0.01$, Figure 2D).

Finally, to further confirm the apoptosis induced by baicalein, the expression of apoptosis-related genes and proteins was detected by qRT-PCR and Western blotting. As presented in Figure $2 \mathrm{E}$ and $\mathrm{F}(P<0.05, P<0.01)$, the levels of Bax were increased, by contrast, levels of Bcl-2 were decreased in MCF-7 and MDA-MB-231 cells after treatment with baicalein compared to the control group. Taken together, our experimental data demonstrated that baicalein could induce apoptosis in breast cancer cells in a dose- and time-dependent manner.

\section{Baicalein induces autophagy in MCF-7 and MDA-MB-23 I cells}

AO staining revealed that baicalein induced the formation of autophagic vacuoles in MCF-7 and MDA-MB-231 cells in a dose-dependent manner. As presented in Figure 3A, compared with the control cells, baicalein treatment resulted in pronounced formation of autophagic vacuoles in MCF-7 and MDA-MB-231 cells.

Morphological and ultrastructural features of MCF-7 and MDA-MB-231 cells were visualized by TEM. Cells were treated with $40 \mu \mathrm{M}$ baicalein for 48 hours. Compared with the control cells, we monitored a large number of autophagy bodies and autophagolysosome in MCF-7 and MDA-MB-231 cells treated with baicalein (Figure 3B).

To further confirm the autophagy induced by baicalein, the expression of autophagy-related genes and proteins was detected by qRT-PCR and Western blotting. As presented in Figure $3 \mathrm{C}$ and $\mathrm{D}(P<0.05, P<0.01)$, the levels of LC3B and BECN1 were increased significantly in MCF-7 and MDA-MB-231 cells treated with baicalein in a dose- and time-dependent manner. These results provided real evidence of baicalein-induced autophagy of breast cancer cells.

\section{Baicalein regulates the apoptosis and autophagy of breast cancer cells via the $\mathrm{PI3K} / \mathrm{AKT}$ /AKT signaling pathway}

In order to elucidate the underlying molecular mechanism of baicalein-induced apoptosis and autophagy, the levels of proteins associated with the PI3K/AKT signaling pathway were examined using Western blotting. The results suggested that compared with the control group, p-AKT, p-mTOR, $\mathrm{NF}-\kappa \mathrm{B}$, and $\mathrm{p}-\mathrm{I} \kappa \mathrm{B}$ protein expression was significantly downregulated in MCF-7 and MDA-MB-231 cells following treatment with different concentrations $(0,10,20$, and $40 \mu \mathrm{M})$ of baicalein for 24 hours, 48 hours, and 72 hours, whereas the expression of $\mathrm{I} \kappa \mathrm{B}$ was up-regulated at the protein level in a dose- and time-dependent manner (Figure 4A). Besides, the $\mathrm{p}-\mathrm{AKT} / \mathrm{AKT}$ and $\mathrm{p}-\mathrm{mTOR} / \mathrm{mTOR}$ ratios were also reduced in a dose- and time-dependent manner (Figure 4B, $P<0.05$, $P<0.01)$. Collectively, these results illustrated that baicalein regulates the apoptosis and autophagy of breast cancer cells via the PI3K/AKT pathway.

To further confirm the effects of baicalein on PI3K/AKT signaling pathway, LY294002, a specific PI3K inhibitor, was then used. Treatment of breast cancer cells with LY294002 resulted in a reduction in $\mathrm{p}-\mathrm{AKT}$. The levels of $\mathrm{p}$-mTOR were also decreased compared with the controls (Figure 4C, $P<0.05, P<0.01)$. These findings support the hypothesis that the induction of apoptosis and autophagy in cells by baicalein is mediated by the suppression of the PI3K/AKT signaling pathway.

\section{In vivo effects of baicalein on breast cancer xenograft model}

In vitro, we had clarified that baicalein can inhibit proliferation and induce apoptosis and autophagy in MCF-7 and MDA-MB-231 cells. Next, we established whether baicalein had similar effects in vivo. Consequently, we assessed the anticancer potential of baicalein using breast xenografts models (BALB/c-nude) as the testing model. After therapeutic treatment with baicalein, tumor tissues from breast xenograft models were collected and analyzed. The results demonstrated that the growth, volume, and weight of tumors were significantly suppressed in the baicalein-treated group compared with the control group (Figure $5 \mathrm{~A}-\mathrm{C}, P<0.05$ ). Additionally, 


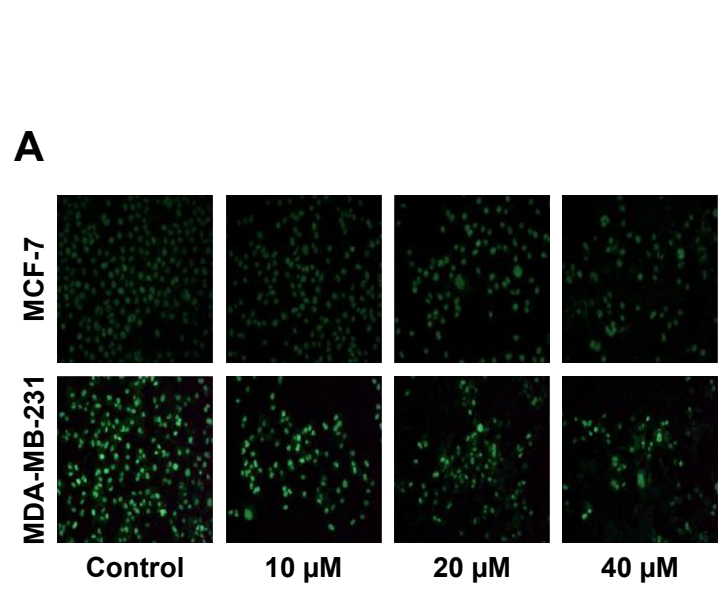

C
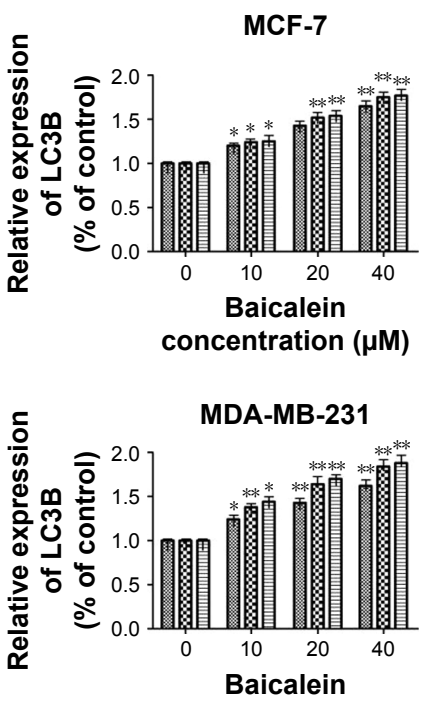

concentration $(\mu \mathrm{M})$

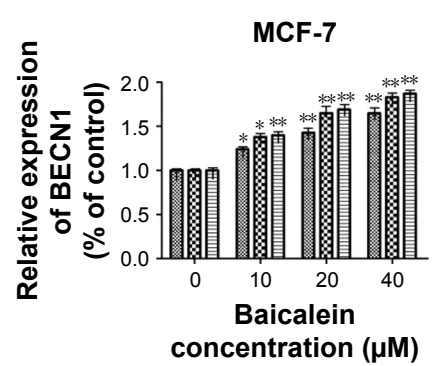

MDA-MB-231

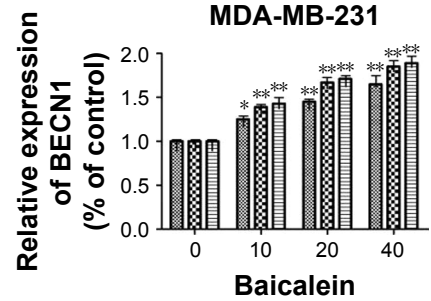

concentration $(\mu \mathrm{M})$
B
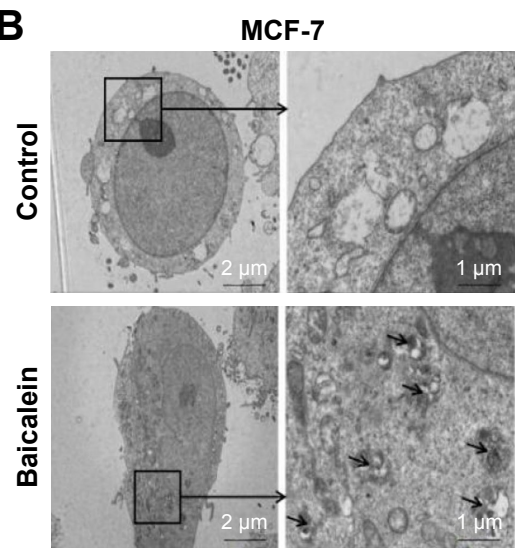

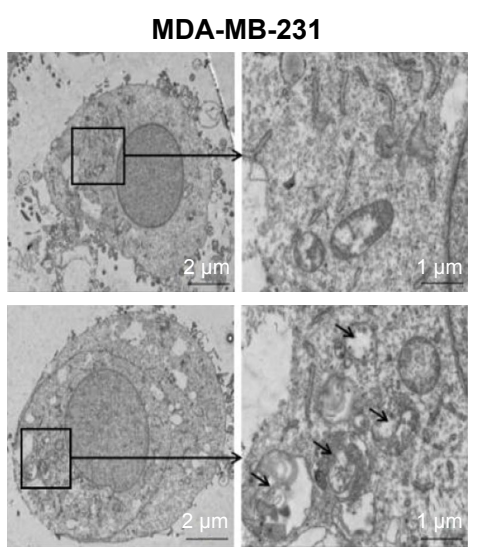

D

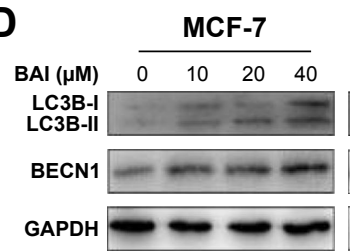

MDA-MB-231
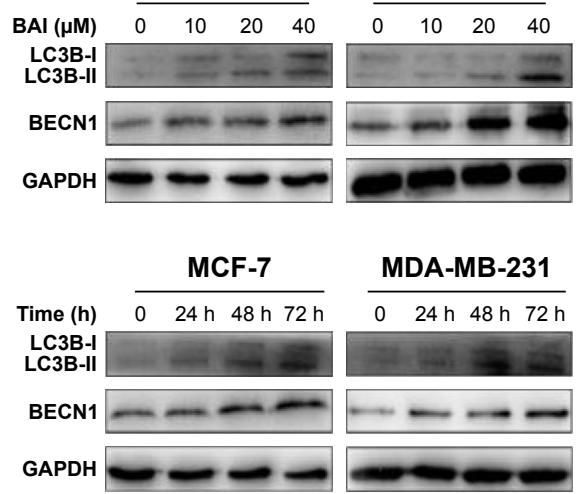

MDA-MB-231

$0 \quad 24 \mathrm{~h} 48 \mathrm{~h} 72 \mathrm{~h}$

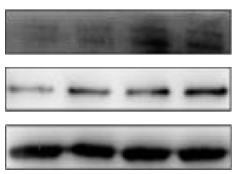

Figure 3 Determination of the induction of autophagy in MCF-7 and MDA-MB-23I breast cancer cells.

Notes: (A) MCF-7 and MDA-MB-23I cells were treated with baicalein at concentrations of $0,10,20$, and $40 \mu$, and acridine orange (AO) staining was performed to detect the formation of acidic vesicular organelles (AVOs) in autophagic cells. The microscopic images indicated progressive increases in AVOs in the cells as the baicalein concentration increased (AO staining, magnification $\times 200)$. (B) Transmission electron microscopy was used to observe autophagy. A large number of autophagy bodies and autophagolysosome (arrows) were monitored in MCF-7 and MDA-MB-23I cells treated for 48 hours with baicalein (magnification $\times 6,000)$. (C, D) Baicalein induced the activation of autophagy-related genes and proteins in MCF-7 and MDA-MB-23I cells. After treatment with baicalein (0, I0, 20, and 40 $\mu$ mol/L) for 24,48 , and 72 hours, cell lysates were prepared and qRT-PCR and Western blot analysis were performed against LC-3B and BECNI. GAPDH was used as a loading control. The results shown are representative of at least three independent experiments. $* P<0.05$, $* * P<0.01$.

Abbreviation: qRT-PCR, quantitative real-time PCR.

we assessed the anti-tumor efficacy of baicalein in vivo by immunohistochemistry staining methods. As presented in Figure 5D, baicalein remarkably reduced the expression of p-AKT, while increasing the expression of Bax and LC3 at the protein level. These results illustrated that baicalein can significantly induce apoptosis and autophagy through negative modulation of the PI3K/AKT pathway in vivo, in accordance with our in vitro research findings.

\section{Discussion}

Baicalein has been isolated from the roots of $S$. baicalensis, and it has been confirmed to be effective against various cancer cells both in vitro ${ }^{9,10}$ and in vivo. ${ }^{11,24}$ However, the properties of baicalein regarding anti-proliferation and induction of apoptosis and autophagy and the specific mechanism(s) in breast cancer cells have not been elucidated. The anti-tumor function of baicalein has not been investigated in clinical trials, further study of the mechanisms that underpin baicalein anti-tumor activity may provide possible clinical applications for the treatment of breast cancer. Our study illuminated that baicalein induces apoptosis and autophagy by inhibition of the PI3K/AKT signaling pathway.

Cell apoptosis and autophagy, as the critical formation of type I and II programmed cell death, have been closely associated with tumorigenicity and tumor development and could be regarded as a potential useful strategy in anti-tumor 


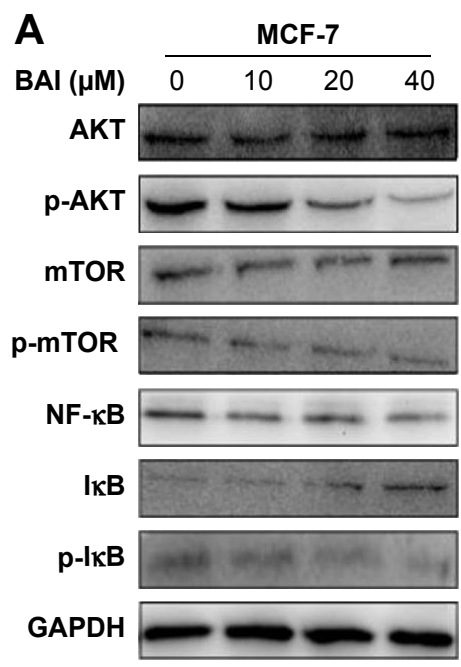

B
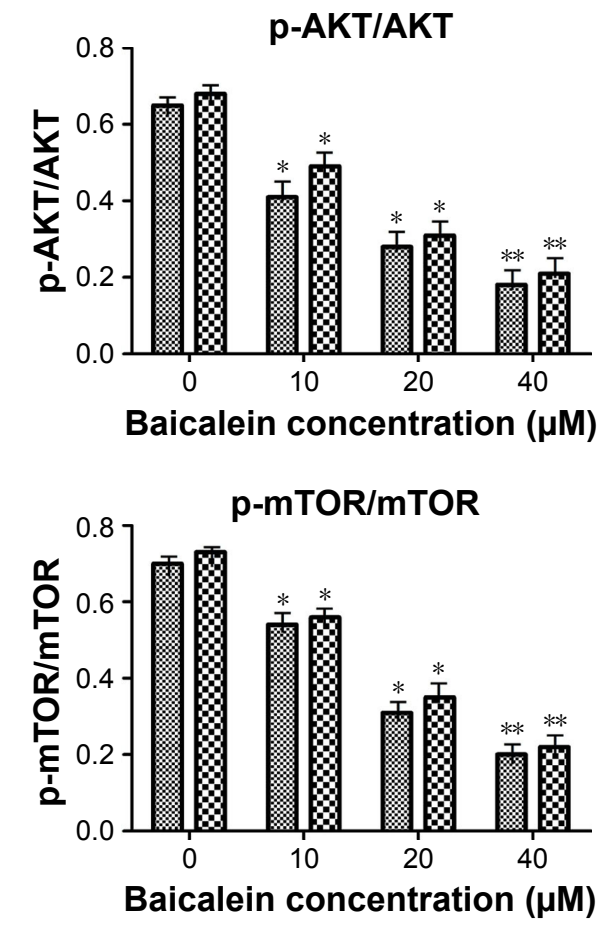

MDA-MB-231

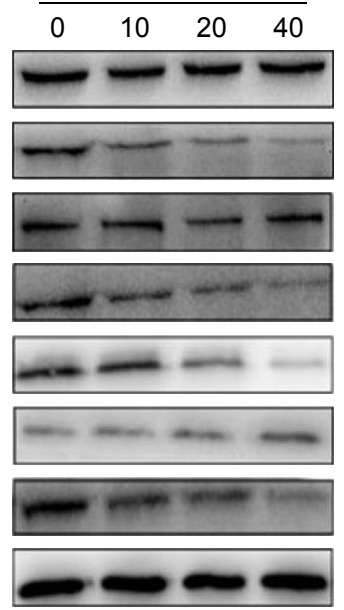

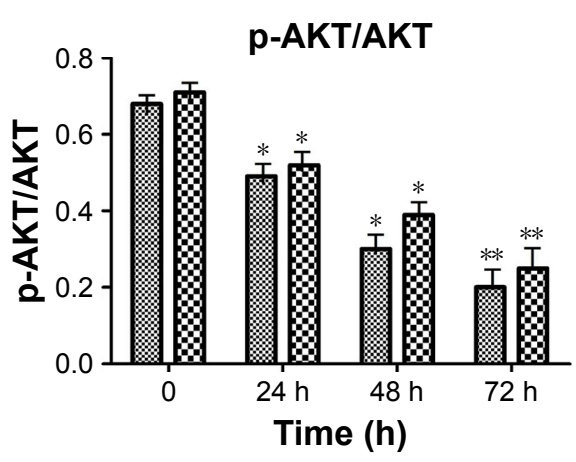
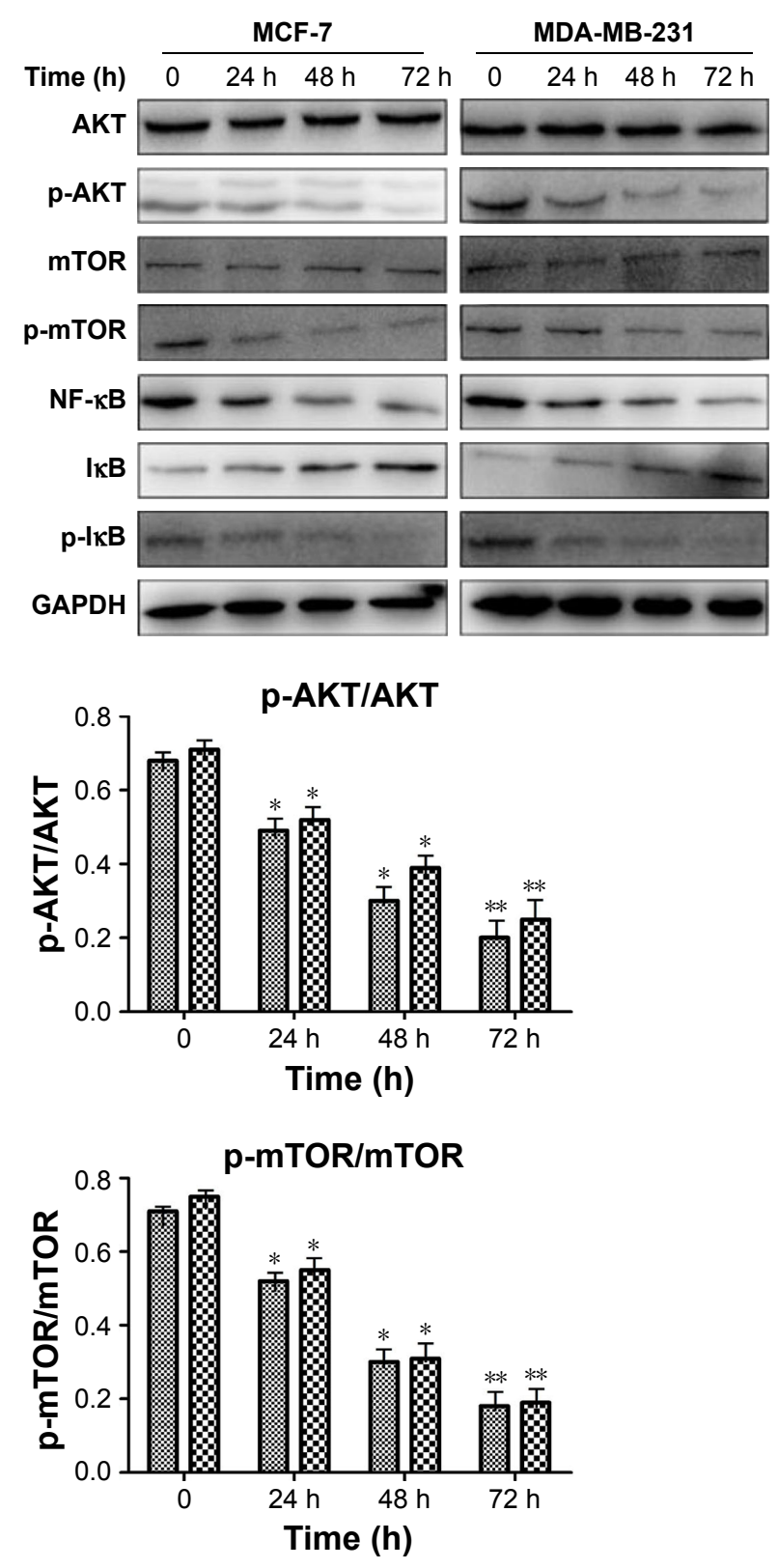

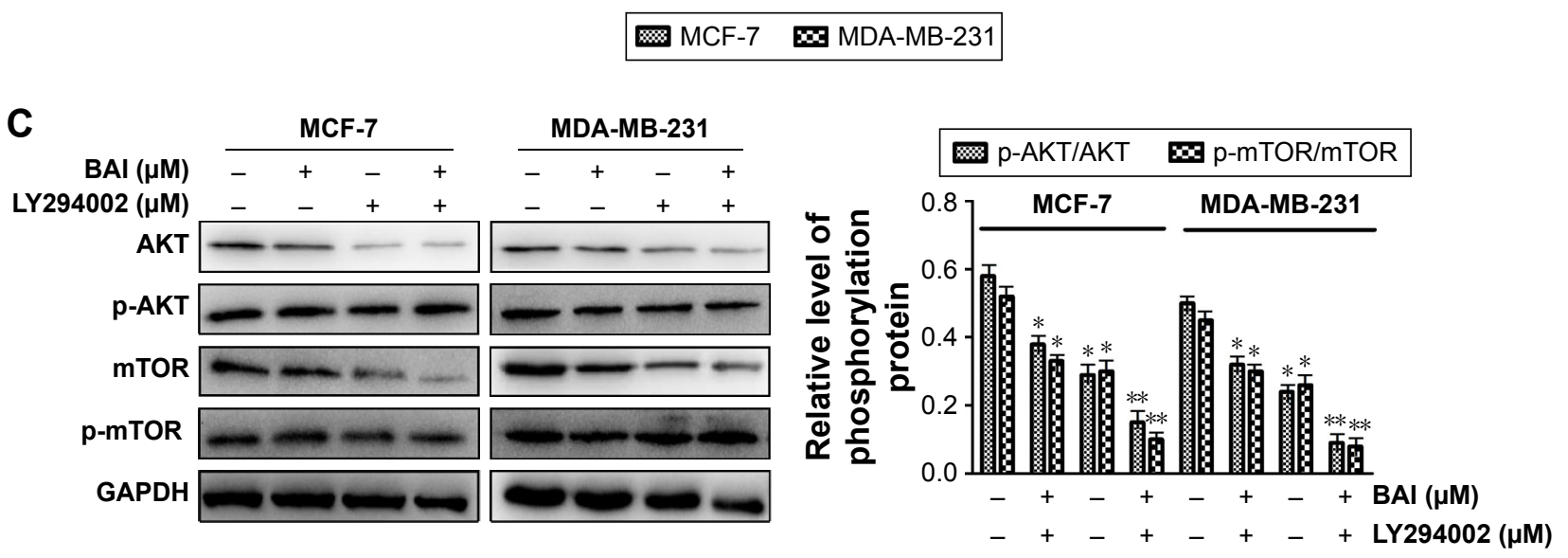

Figure 4 Expression of proteins associated with the PI3K/Akt signaling following various treatment times of MCF-7 and MDA-MB-23I cells with baicalein (0, I0, 20, and 40 $\mu$ M). Notes: Expression of GAPDH, AKT, p-AKT, mTOR, p-mTOR, NF- $\kappa B$, I $/ \mathrm{B}$, and $\mathrm{p}-\mathrm{I} \mathrm{KB}$ was analyzed by Western blot analysis (A) and the relative ratio of P-AKT/AKT, p-mTOR/mTOR. (B) was calculated by the density. (C) Inhibition of LY294002, following 48 hours of treatment with baicalein, and the effect on the phosphorylation of Akt and $\mathrm{mTOR}$ in breast cancer cells. $* \mathrm{P}<0.05, * * \mathrm{P}<0.01$. 

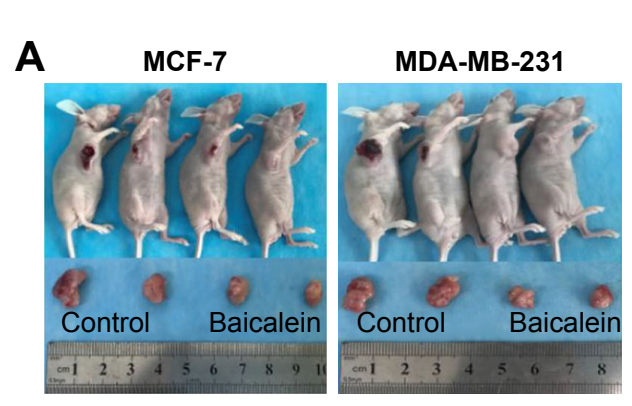
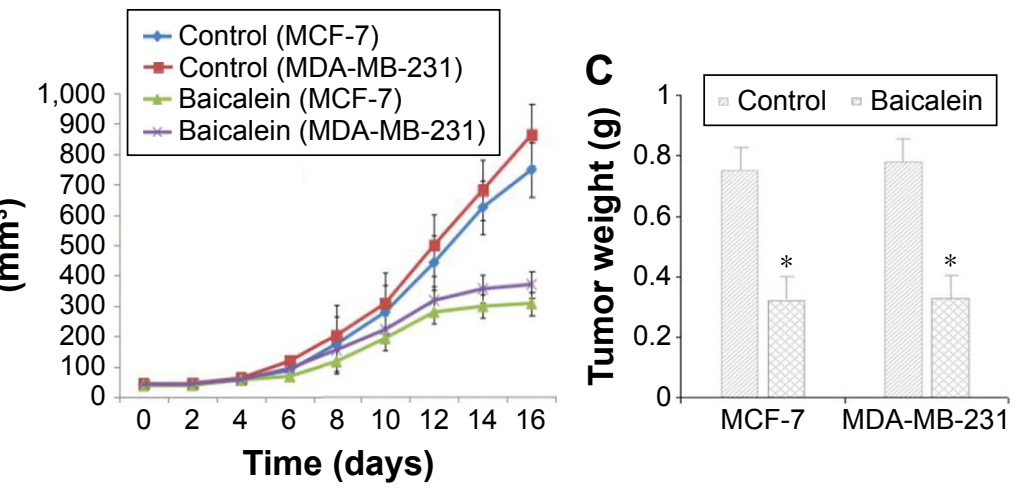

D

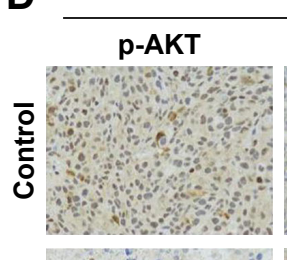

MCF-7

Bax
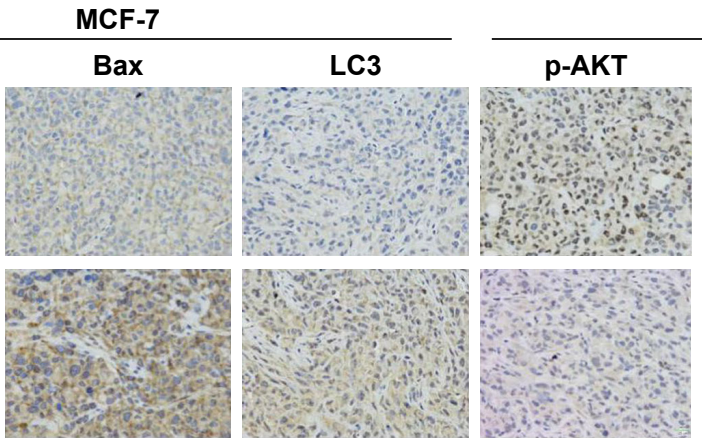

MDA-MB-231
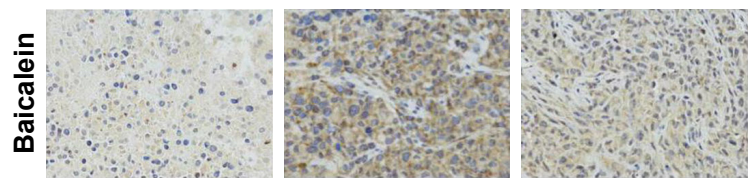

Figure 5 Baicalein inhibited MCF-7 and MDA-MB-23I tumor xenograft growth in vivo.

Notes: Tumor volume (A, B) and weight (C) were measured in control and baicalein groups. (D) Tumors were excised and processed for immunohistochemical staining for P-AKT, Bax, and LC3 in MCF-7 and MDA-MB-23I cells (original magnification $\times 200$ ). Each value is mean $\pm S D ; * P<0.05$.

therapy. ${ }^{25}$ Previous in vivo and in vitro studies have indicated that baicalein induces apoptosis in non-small-cell lung cancer, ${ }^{26}$ human cervical cancer HeLa cells, ${ }^{27}$ esophageal squamous cell carcinoma cells, ${ }^{28}$ and Burkitt lymphoma cells. ${ }^{29}$ However, there is a lack of information regarding the anticancer activity of baicalein in breast cancer cells, and its effects on the signaling pathways related to apoptosis and autophagy remain unclear. In this present study, first, we established that baicalein inhibited cell proliferation in a timeand dose-dependent manner in MCF-7 and MDA-MB-231 cells by MTT and clone formation assays. Then, we observed that baicalein induced apoptosis in two breast cancer cell lines via Hoechst staining, mitochondrial membrane potential $(\Delta \Psi \mathrm{m})$, and annexin V-FITC assay, respectively. In addition, the BCL-2 family is a crucial mediator and plays a vital role in cell apoptosis, ${ }^{30}$ including anti-apoptotic protein (BCL-2) and pro-apoptotic protein (Bax). ${ }^{31}$ These findings showed that baicalein induced apoptosis by increasing the Bax/BCL-2 ratio, as measured by qRT-PCR and Western blotting. Next, we assessed the potential of baicalein-induced autophagy. BECN1 and LC3, a central protein and the initiator of autophagy, respectively, are regarded as autophagy-related proteins, and participate in the autophagy signaling pathway, including autophagosome formation ${ }^{32,33}$ and autophagosome maturation. ${ }^{34,35}$ In mammals, LC3B, one of three isoforms (LC3A, B, and C), has extensive tissue specificities and is widely applied in the research of autophagy. ${ }^{21}$ They are considered as vital molecular events, involving the conversion of LC3B-I to LC3B-II and increase of BECN1, observed in the process of autophagy. We analyzed autophagic cells through acidic vesicular organelle staining assay, and detected autophagosomes under TEM. The expression of BECN1 and LC3 was significantly increased as shown by qRT-PCR and Western blotting.

The PI3K/AKT signaling pathway plays a crucial role in not only regulating normal cell proliferation, differentiation, and apoptosis, ${ }^{36}$ but also in modulating the development and progression of human cancers, once this signaling has been activated. ${ }^{37,38} \mathrm{AKT}, \mathrm{NF}-\mathrm{\kappa B}$, and $\mathrm{mTOR}^{39,40}$ are the downstream components of the PI3K/AKT signaling pathway, ${ }^{41}$ and when continuously activated, they are thought to function significantly in maintenance of malignancies. ${ }^{42}$ Previous studies $^{21}$ revealed that the NF- $\kappa B$ and mTOR pathways play a vital role in cell growth, as well as progression, apoptosis, and metastasis in human cancer cells..$^{43,44}$ To further illuminate the specific mechanisms involved in the effects of baicalein-apoptosis and autophagy on breast cancer cells in vitro, we applied Western blot to evaluate the expression 
level of various proteins (AKT, p-AKT, mTOR, p-mTOR, $\mathrm{NF}-\kappa \mathrm{B}, \mathrm{I} \kappa \mathrm{B}$, and $\mathrm{p}-\mathrm{I} \kappa \mathrm{B})$ in the $\mathrm{PI} 3 \mathrm{~K} / \mathrm{AKT}$ pathway in MCF-7 and MDA-MB-231 cells. The results showed that baicalein remarkably reduced the expression of $\mathrm{p}-\mathrm{AKT}$, $\mathrm{p}-\mathrm{mTOR}, \mathrm{NF}-\kappa \mathrm{B}$, and $\mathrm{p}-\mathrm{I} \kappa \mathrm{B}$, while increasing the expression of $\mathrm{I} \kappa \mathrm{B}$ at the protein level in baicalein-treated MCF-7 and MDA-MB-231 cells. Besides, the p-AKT/AKT and $\mathrm{p}-\mathrm{mTOR} / \mathrm{mTOR}$ ratios were also reduced in a dose- and timedependent manner. Moreover, we observed that LY294002, a specific PI3K inhibitor, decreased the levels of p-AKT and p-mTOR. These findings further supported the hypothesis that the induction of apoptosis and autophagy in cells by baicalein is mediated by the suppression of the PI3K/AKT pathway. In addition, to acquire more reliable evidence to support and verify our in vitro experimental findings, we used the xenograft nude mouse model to clarify the underlying molecular mechanisms of baicalein-apoptosis and autophagy in breast cancer cells in vivo. Results acquired from the in vitro study were in accordance with those of in vivo.

\section{Conclusion}

Taken together, our results demonstrated that baicalein had the potential to suppress cell proliferation, induce apoptosis and autophagy in MCF-7 and MDA-MB-231 breast cancer cells through inhibiting the PI3K/AKT pathway both in vitro and in vivo. These results suggest that baicalein may have therapeutic potential for breast cancer treatment and deserves further study. The anti-tumor function of baicalein has not been investigated in clinical trials, further study of the mechanisms that underpin baicalein's anti-tumor activity may provide possible clinical applications in the treatment of breast cancer.

\section{Acknowledgments}

This study was funded by the National Natural Science Foundation of China (Nos. 81274136, 81471670), Program for New Century Excellent Talents in Universities of China (No. NCET-110439). Shuqun Zhang provided funding for the study.

\section{Disclosure}

The authors report no conflicts of interest in this work.

\section{References}

1. Beiki O, Hall P, Ekbom A, Moradi T. Breast cancer incidence and case fatality among 4.7 million women in relation to social and ethnic background: a population-based cohort study. Breast Cancer Res. 2012; 14(1):R5.

2. Torre LA, Bray F, Siegel RL, Ferlay J, Lortet-Tieulent J, Jemal A. Global cancer statistics, 2012. CA Cancer J Clin. 2015;65(2):87-108.
3. Christophe V, Duprez C, Congard A, et al. The subjective experience of young women with non-metastatic breast cancer: the Young Women with Breast Cancer Inventory. Health Qual Life Outcomes. 2015;13:73.

4. Miocinovic R, McCabe NP, Keck RW, Jankun J, Hampton JA, Selman SH. In vivo and in vitro effect of baicalein on human prostate cancer cells. Int J Oncol. 2005;26(1):241-246.

5. Schmidt MK, van den Broek AJ, Tollenaar RA, et al. Breast Cancer Survival of BRCA1/BRCA2 Mutation Carriers in a Hospital-Based Cohort of Young Women. J Natl Cancer Inst. 2017;109(8).

6. Kimura Y, Kubo M, Tani T, Arichi S, Ohminami H, Okuda H. Studies on Scutellariae radix. III. Effects on lipid metabolism in serum, liver and fat cells of rats. Chem Pharm Bull. 1981;29(8):2308-2312.

7. Lin CC, Shieh DE. The anti-inflammatory activity of Scutellaria rivularis extracts and its active components, baicalin, baicalein and wogonin. Am J Chin Med. 1996;24(1):31-36.

8. Lu Y, Joerger R, Wu C. Study of the chemical composition and antimicrobial activities of ethanolic extracts from roots of Scutellaria baicalensis Georgi. J Agric Food Chem. 2011;59(20):10934-10942.

9. Ma Z, Otsuyama K, Liu S, et al. Baicalein, a component of Scutellaria radix from Huang-Lian-Jie-Du-Tang (HLJDT), leads to suppression of proliferation and induction of apoptosis in human myeloma cells. Blood. 2005;105(8):3312-3318.

10. Martínez ME, Unkart JT, Tao L, et al. Prognostic significance of marital status in breast cancer survival: A population-based study. PLoS One. 2017;12(5):e0175515.

11. Chen CH, Huang LL, Huang CC, Lin CC, Lee Y, Lu FJ. Baicalein, a novel apoptotic agent for hepatoma cell lines: a potential medicine for hepatoma. Nutr Cancer. 2002;38(2):287-295.

12. Lee HZ, Leung HW, Lai MY, Wu CH. Baicalein induced cell cycle arrest and apoptosis in human lung squamous carcinoma $\mathrm{CH} 27$ cells. Anticancer Res. 2005;25(2A):959-964.

13. Huang Y, Hu J, Zheng J, et al. Down-regulation of the PI3K/Akt signaling pathway and induction of apoptosis in CA46 Burkitt lymphoma cells by baicalin. J Exp Clin Cancer Res. 2012;31(1):48.

14. Zhang HB, Lu P, Guo QY, Zhang ZH, Meng XY. Baicalein induces apoptosis in esophageal squamous cell carcinoma cells through modulation of the PI3K/Akt pathway. Oncol Lett. 2013;5(2):722-728.

15. Huang KF, Zhang GD, Huang YQ, Diao Y. Wogonin induces apoptosis and down-regulates survivin in human breast cancer MCF-7 cells by modulating PI3K-AKT pathway. Int Immunopharmacol. 2012;12(2): 334-341.

16. Seo BR, Min KJ, Cho IJ, Kim SC, Kwon TK. Curcumin significantly enhances dual PI3K/Akt and mTOR inhibitor NVP-BEZ235-induced apoptosis in human renal carcinoma Caki cells through down-regulation of p53-dependent Bcl-2 expression and inhibition of Mcl-1 protein stability. PLoS One. 2014;9(4):e95588.

17. Cao X, Liu B, Cao W, et al. Autophagy inhibition enhances apigenininduced apoptosis in human breast cancer cells. Chin J Cancer Res. 2013;25(2):212-222.

18. Annovazzi L, Mellai M, Caldera V, Valente G, Tessitore L, Schiffer D. mTOR, S6 and AKT expression in relation to proliferation and apoptosis/ autophagy in glioma. Anticancer Res. 2009;29(8):3087-3094.

19. Sun H, Wang Z, Yakisich JS. Natural products targeting autophagy via the PI3K/Akt/mTOR pathway as anticancer agents. Anticancer Agents Med Chem. 2013;13(7):1048-1056.

20. Li H, Gao Q, Guo L, Lu SH. The PTEN/PI3K/Akt pathway regulates stem-like cells in primary esophageal carcinoma cells. Cancer Biol Ther. 2011;11(11):950-958.

21. Li B, Cheung PY, Wang X, et al. Id-1 activation of PI3K/Akt/NFkappaB signaling pathway and its significance in promoting survival of esophageal cancer cells. Carcinogenesis. 2007;28(11):2313-2320.

22. Agarwal S, Achari C, Praveen D, Roy KR, Reddy GV, Reddanna P. Inhibition of 12-LOX and COX-2 reduces the proliferation of human epidermoid carcinoma cells (A431) by modulating the ERK and PI3K-Akt signalling pathways. Exp Dermatol. 2009;18(11): 939-946. 
23. Chao JI, Su WC, Liu HF. Baicalein induces cancer cell death and proliferation retardation by the inhibition of CDC2 kinase and survivin associated with opposite role of p38 mitogen-activated protein kinase and AKT. Mol Cancer Ther. 2007;6(11):3039-3048.

24. Lee HZ, Leung HW, Lai MY, Wu CH. Baicalein induced cell cycle arrest and apoptosis in human lung squamous carcinoma $\mathrm{CH} 27$ cells. Anticancer Res. 2005;25(2A):959-964.

25. Ma C, Zhu L, Wang J, et al. Anti-inflammatory effects of water extract of Taraxacum mongolicum Hand.-Mazz on lipopolysaccharide-induced inflammation in acute lung injury by suppressing PI3K/Akt/mTOR signaling pathway. J Ethnopharmacol. 2015;168:349-355.

26. Cathcart MC, Useckaite Z, Drakeford C, et al. Anti-cancer effects of baicalein in non-small cell lung cancer in-vitro and in-vivo. $B M C$ Cancer. 2016;16:707.

27. Peng Y, Guo C, Yang Y, et al. Baicalein induces apoptosis of human cervical cancer HeLa cells in vitro. Mol Med Rep. 2015;11(3):2129-2134.

28. Zhang HB, Lu P, Guo QY, Zhang ZH, Meng XY. Baicalein induces apoptosis in esophageal squamous cell carcinoma cells through modulation of the PI3K/Akt pathway. Oncol Lett. 2013;5(2):722-728.

29. Huang Y, Hu J, Zheng J, et al. Down-regulation of the PI3K/Akt signaling pathway and induction of apoptosis in CA46 Burkitt lymphoma cells by baicalin. J Exp Clin Cancer Res. 2012;31:48.

30. Adams JM, Cory S. The Bcl-2 protein family: arbiters of cell survival. Science. 1998;281(5381):1322-1326.

31. Kim R. Unknotting the roles of Bcl-2 and Bcl-xL in cell death. Biochem Biophys Res Commun. 2005;333(2):336-343.

32. Kang R, Zeh HJ, Lotze MT, Tang D. The Beclin 1 network regulates autophagy and apoptosis. Cell Death Differ. 2011;18(4):571-580.

33. Yorimitsu T, Klionsky DJ. Autophagy: molecular machinery for selfeating. Cell Death Differ. 2005;12(Suppl 2):1542-1552.
34. Barth S, Glick D, Macleod KF. Autophagy: assays and artifacts. $J$ Pathol. 2010;221(2):117-124.

35. He C, Levine B. The Beclin 1 interactome. Curr Opin Cell Biol. 2010; 22(2):140-149.

36. Kauffmann-Zeh A, Rodriguez-Viciana P, Ulrich E, et al. Suppression of c-Myc-induced apoptosis by Ras signalling through PI(3)K and PKB. Nature. 1997;385(6616):544-548.

37. Song L, Xiong H, Li J, et al. Sphingosine kinase-1 enhances resistance to apoptosis through activation of PI3K/Akt/NF-KB pathway in human non-small cell lung cancer. Clin Cancer Res. 2011;17(7):1839-1849.

38. Tsuruta F, Masuyama N, Gotoh Y. The phosphatidylinositol 3-kinase (PI3K)-Akt pathway suppresses Bax translocation to mitochondria. J Biol Chem. 2002;277(16):14040-14047.

39. Kawauchi K, Ogasawara T, Yasuyama M, Otsuka K, Yamada O. The PI3K/Akt pathway as a target in the treatment of hematologic malignancies. Anticancer Agents Med Chem. 2009;9(5):550-559.

40. Vu C, Fruman DA. Target of rapamycin signaling in leukemia and lymphoma. Clin Cancer Res. 2010;16(22):5374-5380.

41. Chen Y, Wang BC, Xiao Y. PI3K: a potential therapeutic target for cancer. J Cell Physiol. 2012;227(7):2818-2821.

42. Dazert E, Hall MN. mTOR signaling in disease. Curr Opin Cell Biol. 2011;23(6):744-755.

43. Sun SY, Rosenberg LM, Wang X, et al. Activation of Akt and eIF4E survival pathways by rapamycin-mediated mammalian target of rapamycin inhibition. Cancer Res. 2005;65(16):7052-7058.

44. Xu G, Zhang W, Bertram P, Zheng XF, Mcleod H. Pharmacogenomic profiling of the PI3K/PTEN-AKT-mTOR pathway in common human tumors. Int J Oncol. 2004;24(4):893-900.
Drug Design, Development and Therapy

\section{Publish your work in this journal}

Drug Design, Development and Therapy is an international, peerreviewed open-access journal that spans the spectrum of drug design and development through to clinical applications. Clinical outcomes, patient safety, and programs for the development and effective, safe, and sustained use of medicines are the features of the journal, which

\section{Dovepress}

has also been accepted for indexing on PubMed Central. The manuscript management system is completely online and includes a very quick and fair peer-review system, which is all easy to use. Visit http://www.dovepress.com/testimonials.php to read real quotes from published authors. 